\title{
SPATIAL VARIABILITY OF PORES IN OXIDIC LATOSOL UNDER A CONSERVATION MANAGEMENT SYSTEM WITH DIFFERENT GYPSIUM DOSES
}

\author{
Variabilidade espacial de poros em Latossolo oxídico sob sistema de manejo \\ conservacionista com diferentes doses de gesso
}

\author{
Carla Eloize Carducci ${ }^{1}$, Geraldo César Oliveira ${ }^{2}$, Nilton Curi ${ }^{2}$, \\ Diogo Francisco Rossoni ${ }^{3}$, Alisson Lucrécio Costa ${ }^{2}$, Richard Jonh Heck ${ }^{4}$
}

\begin{abstract}
Soil structure is modify when subjected to the agricultural process, i.e., a new spatial organization of the pores system is formed, with relation to the physical quality of it. Thus the aim of this work was to visualize and quantify, through X-ray CT scan, the pores distribution in an oxidic Latosol submitted to a conservation management system with different gypsum doses. Three random trenches were dug lengthwise along the plant row in a very clayey gibbsitic dystrophic Red Latosol, subjected to the following gypsum levels: G0: absence of gypsum; G7: $7 \mathrm{Mg}$ ha-1 and G28: $28 \mathrm{Mg}$ ha-1 of additional gypsum, applied to the surface of the plant row. Undisturbed soil samples were collected in plexiglass tubes at depths of 0.20-0.34, 0.80-0.94 and 1.50-1.64 m after six years of coffee cultivation for quantification of 3D pores obtained by X-ray CT scan. The spatial variability of the soil structure was evaluated by semivariograms generated by $3 \mathrm{D}$ images in grayscale. Distribution of the detectable pore diameter was conducted by data mining. Statistical analyzes employed packages 'geoR' to semivariogram and 'randomForest' for data mining in R language. A greater spatial continuity of the pores occurred in the G7 at the three depths. The combined effects of the management system promoted a greater spatial variability of the soil structure in the G28 treatment. Based on geostatistical analyses, it can be infer that the adoption of the system under study promoted changes in the pore network in all directions (X, Y and Z), however with better pores continuity in the vertical direction(Z).
\end{abstract}

Index terms: X-ray CT scan, spatial pore continuity, pores distribution, coffee crop.

\section{RESUMO}

A estrutura do solo é alterada quando submetida ao processo agrícola, ou seja, uma nova organização espacial do sistema poroso é formada com reflexo na qualidade física do mesmo. Dessa forma, objetivou-se, neste trabalho, visualizar e quantificar, por meio da tomografia computada de raios- $\mathrm{X}$, a variabilidade na distribuição do diâmetro de poros em Latossolo oxidíco submetido a um sistema de manejo conservacionista que utiliza diferentes doses de gesso. Foram abertas três trincheiras aleatórias e longitudinais à linha de plantio em um Latossolo Vermelho distrófico gibbsítico muito argiloso, submetido às seguintes doses de gesso: G0: ausência de gesso; G7: $7 \mathrm{Mg} \mathrm{ha}^{-1}$ e G28: $28 \mathrm{Mg} \mathrm{ha}^{-1}$ de gesso adicional, aplicados na superfície do solo na linha de plantio. Amostras com estrutura preservada foram coletadas em cilindros de acrílico, nas profundidades de $0,20-0,34,0,80-0,94$ e 1,50-1,64 m, após seis anos de cultivo dos cafeeiros ,para quantificação dos poros $3 \mathrm{D}$, detectados pela tomografia computada de raios-X. A variabilidade espacial da estrutura do solo foi avaliada por meio de semivariogramas gerados a partir das imagens 3D na escala de cinza. A distribuição do diâmetro dos poros detectáveis foi feita por meio da mineração de dados. Paras as inferências estatísticas, foram utilizados os pacotes 'geoR' para os semivariogramas e 'randomForest' para a mineração de dados em linguagem R. A maior continuidade espacial dos poros ocorreu no tratamento G7 nas três profundidades. Os efeitos combinados do sistema de manejo promoveram a maior variabilidade espacial da estrutura do solo no tratamento G28.Com base nos semivariogramas, pode-se inferir que a adoção do sistema em estudo promoveu modificações na rede de poros em todas as direções (X, Y e Z), porém com melhor continuidade dos poros na direção vertical (Z).

Termos para indexação: Tomografia de raios-X, continuidade espacial, distribuição de poros, cafeicultura.

\section{INTRODUCTION}

The management of agricultural systems affects the soil physical attributes and thus the pore spatial organization, which justifies studies that seek to evaluate soil structural quality. Soil structure is formed by aggregates and a wide network of pores, especially inter-aggregate pores, ensuring good functioning of the hydric, physico-chemical and biological processes and plant performance (Luo; Lin, Li, 2010; Martin et al. 2012).

Particularly in oxidic Latosols, gibbsite, iron oxides and organic matter, in that order, act as disorganizing

\footnotetext{
${ }^{1}$ Universidade Federal de Santa Catarina/UFSC - Rod. Ulysses Gaboardi - km 3 - Cx. P. 101 - 89520-000 - Curitibanos - SC - Brasil - ec.carducci@ufsc.br 2Universidade Federal de Lavras/UFLA - Departamento de Ciência do Solo/DCS - Lavras - MG - Brasil

${ }^{3}$ Universidade Estadual de Maringa/UEM - Departamento de Estatística - Maringá - PR - Brasil

${ }^{4}$ University of Guelph/U of G - Guelph - Ontário - Canada

Received in february 17, 2014 and approved in july 22, 2014
}

Ciênc. Agrotec., Lavras, v.38, n.5, p.445-460, set./out., 2014 
agents of the blocky structure predisposing them to the formation of smaller and more rounded granules (Ferreira, Fernandes; Curi,1999; Vidal-Torrado et al. 1999), which results in a high total porosity, especially of inter-aggregate pores (Cooper; Vidal-Torrado, 2005), which are easily altered by soil management (Oliveira et al. 2004; Severiano et al. 2013).

In these Latosols, when subjected to agricultural management systems, the inter-aggregate pores are seriously affected by the first few passes of machinery, given its high susceptibility to compaction (Severiano et al. 2013.) Therefore, any alteration made by anthropic factors should be evaluated, among other purposes, to detail the possible causes of spatial pore variability (Munkholm; Heck; Deen, 2012; Luo; Lin; Li, 2010).

In this context, the use of a management system that employs conservation practices in coffee crops in the Cerrado region is gaining popularity for combining chemical and physical improvements in soil - water relationships acheive to rising productivity and pursuing of environmental sustainability. Within the principles of conservation agriculture (Raij, 2008), this system provides conditions that enhance the coffee root system performance, so that there are improvements in the utilization of the available water at depth and efficient use of nutrients distributed in the soil profile (Serafim et al. 2011).

For the evaluation of changes in soil porosity promoted by management, X-ray CT scan is effective for enabling three-dimensional mapping of the soil structural components, allowing a qualitative and quantitative evaluation (Borges; Pires, 2012).

So, the aim of this work was to visualize and quantify, through X-ray CT scan, the pore distribution in a oxidic Latosol submitted to a conservation management system with different gypsum doses.

\section{MATERIAL AND METHODS}

\section{Study area}

The study was conducted in a coffee plantation in the municipality of São Roque de Minas, physiographic region of the Upper São Francisco, MG, whose coordinates are $20^{\circ} 15^{\prime} 45^{\prime \prime} \mathrm{S}$ e $46^{\circ} 18^{\prime} 17^{\prime \prime} \mathrm{W}$ with $850 \mathrm{~m}$ altitude. The experimental cultivation was established in November/2008 and it has been conducted according to the practices of a soil conservation management system. The region climate is Cwa, according to the Köppen classification, with annual precipitation of $1,344 \mathrm{~mm}$ and a well-defined dry season from May to September (Menegasse; Gonçalves; Fantinel, 2002).

According to the premises of the conservation management system of coffee (Coffea arabica L.) crop, the cultivar yellow Catucaí was planted in a narrow row spacing of $2.50 \times 0.65 \mathrm{~m}$ (between plants and between rows, respectively). Tillage was conducted using one plowing and two harrowings with application of amendments throughout the total area $\left(4 \mathrm{Mg} \mathrm{ha}^{-1}\right.$ dolomitic limestone $+1.92 \mathrm{Mg} \mathrm{ha}^{-1}$ agricultural gypsum).

We used a subsoiler followed by a spade applied fertilizer for the opening of the $0.60 \mathrm{~m}$ deep and $0.50 \mathrm{~m}$ wide furrow and mixed the soil at $0.40 \mathrm{~m}$ depth (Ticianel, 2013), allowing the incorporation of basic fertilizer (formula 08-44-00, enriched with $1.5 \% \mathrm{Zn}$ and $0.5 \% \mathrm{~B})$. This furrow was corrected at greater depth with dolomitic limestone $8 \mathrm{Mg} \mathrm{ha}^{-1}\left(2 \mathrm{~kg} \mathrm{~m}^{-1}\right)$ in all treatments. The coffee seedlings were planted between the second half of October and the first half of November 2008.

After planting, the treatments received different doses of additional gypsum, this amendment being covered with soil material and mixed with the inter-row plant material (mixture piled-up at the base of the coffee plant stem).

Together with the installation of the crop, Brachiaria ducumbens (Syn. Urochloa) was implanted between the planting lines, which were periodically cut with a brush cutter, which minimizes competition with the main crop and allows the plant residue produced to be distributed along the row as well as between rows. This practice is used to improve soil structure and serves as protection against erosive agents (Lima et al. 2012). The related crop operations were carried out by means of animal traction equipment; only the harvesting was done mechanically. The nutritional monitoring and fertilization management of the coffee crop was conducted based on leaf analysis (Serafim et al. 2011; Carducci et al. 2013).

The parcels contain 10 rows with 36 plants each, totaling 360 plants per plot with an area of $585 \mathrm{~m}^{2}$. The boundary corresponds to 3 plants at the beginning of the plot and two rows on the sides, totaling $360 \mathrm{~m}^{2}$.

For this study treatments were included: G0 absence of additional gypsum; G7 -7 $\mathrm{Mg} \mathrm{ha}^{-1}$ and G28 $-28 \mathrm{Mg} \mathrm{ha}^{-1}$ of additional gypsum, both applied on the surface of the plant row. The selection of these treatments was based on the hypothesis of possible structural 
alterations promoted by the application of gypsum and for this we evaluated the recommended dose ages found in the literature (G7), the reference dose for the system adopted itself (G28) and the treatment without additional gypsum (G0).

\section{Soil sampling and physical, chemical and mineralogical characterization}

For the sampling and characterization of soil, three random trenches were dug lengthwise along the plant row, with dimensions of $0.70 \mathrm{~m}$ (width) $\times 1.50 \mathrm{~m}$ (length) $\times 1.50$ $\mathrm{m}$ (depth) and then samples were collected for physical, chemical and CT scan analyses. It is noteworthy to mention that at the sampling time (September/2011) the crop had three years of cultivation.

The intact soil cores were sampled by hand, using plexiglass cylinders $(0.065 \mathrm{~m}$ diameter and 0.14 $m$ height) equipped with a specially designed aluminum sampling ring for CT scan analysis and more volumetric rings $(0.065 \mathrm{~cm}$ diameter and $0.025 \mathrm{~m}$ height $)$ for the remaining analyzes. The sampling occurred between plants $(0.65 \mathrm{~m})$ and just below the gypsum layer at depths of $0.20-0.34,0.80-0.94$ and $1.50-1.64 \mathrm{~m}$, with three replicates for each treatment (G0, G7 and G28), totaling 27 samples.

In the laboratory, the disturbed soil samples collected rightly after the undisturbed samples collection were air-dried and passed through a two-millimeter mesh sieve for further analyze.

The $\mathrm{SiO}_{2}, \mathrm{Al}_{2} \mathrm{O}_{3}$ and $\mathrm{Fe}_{2} \mathrm{O}_{3}$ contentswere determined by sulfuric acid digestion and used in calculations of the $\mathrm{Ki}\left(\mathrm{SiO}_{2} / \mathrm{Al}_{2} \mathrm{O}_{3}\right)$ and $\mathrm{Kr}\left[\mathrm{SiO}_{2} /\right.$ $\left.\left(\mathrm{Al}_{2} \mathrm{O}_{3}+\mathrm{Fe}_{2} \mathrm{O}_{3}\right)\right]$ molecular ratios (Embrapa, 2013). The values of $\mathrm{Ki}$ and $\mathrm{Kr}$ less than 0.75 characterize this soil as very weathered, which is evidence of its sesquioxidic gibbsitic mineralogy. The kaolinite and gibbsite contents were derived from XRD measurements and stoichiometric ratios derived from their ideal chemical formulas, according to Resende, Bahia Filho and Braga(1987) (Table 1).

The particle size analysis was performed by employing slow agitation of the soil suspension, using $\mathrm{NaOH} 1 \mathrm{~mol} \mathrm{~L}^{-1}$ for 16 hours. Mean values in $\mathrm{g} \mathrm{kg}^{-1}$ were, respectively for clay, silt and sand: 819,157 and 24 at a depth of $0.20-0.34 \mathrm{~m} ; 848,127$ and 25 at a depth of 0.80-0.94 $\mathrm{m}$ and 886,89 and 25 at a depth of 1.50-1.64 $\mathrm{m}$. Subsequently, we conducted fertility analyzes, where aliquots of these samples were taken to determine the $\mathrm{pH}$, sorptive complex and organic matter contents of the soil (Embrapa, 2011) (Table 2).

As a function of the chemical and physical characterization and morphological description (Santos et al. 2013), the soil was classified according to Embrapa (2013) as gibbsitic Red Latosol (RL) very clayey.

Table 1 - Chemical and mineralogical characterization of the B horizon of a Red Latosol.

\begin{tabular}{|c|c|c|c|c|c|c|c|}
\hline & \multicolumn{3}{|c|}{ Sulfuric acid digestion } & \multirow[b]{2}{*}{$\mathrm{Ki}^{(1)}$} & \multirow[b]{2}{*}{$\mathrm{Kr}^{(2)}$} & \multirow[b]{2}{*}{$\mathrm{Kt}^{(3)}$} & \multirow[b]{2}{*}{$\mathrm{Gb}^{(4)}$} \\
\hline & $\mathrm{SiO}_{2}$ & $\mathrm{Al}_{2} \mathrm{O}_{3}$ & $\mathrm{Fe}_{2} \mathrm{O}_{3}$ & & & & \\
\hline & \multicolumn{3}{|c|}{$\ldots \ldots \ldots \ldots \ldots \mathrm{g} \mathrm{kg}^{-1} \ldots \ldots \ldots \ldots$} & & & \multicolumn{2}{|c|}{$\ldots \ldots . . \% \ldots$} \\
\hline $\mathrm{Bw}$ & 104.9 & 391.7 & 169.0 & 0.46 & 0.36 & 22.55 & 58.53 \\
\hline
\end{tabular}

${ }^{(1)} \mathrm{Ki}: \mathrm{SiO}_{2}: \mathrm{Al}_{2} \mathrm{O}_{3}$ molecular ratio, ${ }^{(2)} \mathrm{Kr}: \mathrm{SiO}_{2}:\left(\mathrm{Al}_{2} \mathrm{O}_{3}+\mathrm{Fe}_{2} \mathrm{O}_{3}\right)$ molecular ratio, ${ }^{(3)} \mathrm{Kt}$ : kaolinite, ${ }^{(4)} \mathrm{Gb}$ : gibbsite.

Table 2 - Mean values of soil fertility analyses at the $0.15-0.25 \mathrm{~m}$ depth in treatmentsG0: absence of additional gypsum, G7: $7 \mathrm{Mg} \mathrm{ha}^{-1}$ and G28: $28 \mathrm{Mg} \mathrm{ha}^{-1}$ of additional gypsum applied to the soil surface of the plant row.

\begin{tabular}{|c|c|c|c|c|c|c|c|c|c|c|c|c|c|}
\hline \multirow{3}{*}{ Treatment } & \multicolumn{13}{|c|}{$0.15-0.25 \mathrm{~m}$} \\
\hline & $\mathrm{pH}$ & $\mathrm{P}$ & $\mathrm{K}$ & $\mathrm{Ca}$ & $\mathrm{Mg}$ & $\mathrm{Al}$ & $\mathrm{H}+\mathrm{Al}$ & SB & $\mathrm{t}$ & $\mathrm{T}$ & $\mathrm{V}$ & $\mathrm{m}$ & SOM \\
\hline & $\left(\mathrm{H}_{2} \mathrm{O}\right)$ & $\mathrm{mg} \mathrm{dm}{ }^{-3}$ & & & & $\mathrm{~mm}$ & $\mathrm{dm}^{-3}$. & & ...... & & & & $\mathrm{g} \mathrm{kg}^{-1}$ \\
\hline G0 & 5.3 & 3.2 & 109.2 & 27 & 9 & 0 & 43.6 & 39 & 39 & 83 & 47.1 & 0 & 3.79 \\
\hline G7 & 5.4 & 3.4 & 74.8 & 53 & 4 & 0 & 39.3 & 60 & 60 & 98 & 59.2 & 0 & 6.03 \\
\hline G28 & 5.2 & 5.1 & 94.1 & 48 & 8 & 0 & 38.2 & 59 & 59 & 98 & 59.8 & 0 & 5.51 \\
\hline
\end{tabular}

SB: sum of bases; t: effective cation exchange capacity; T: cation exchange capacity at pH7; $\mathrm{V}$ : base saturation; m: aluminum saturation; SOM: soil organic matter. Source: adapted from Silva et al. (2013). 


\section{Acquisition, reconstruction and binarization (Thresholding) of the 3D images}

For the CT scan the soil cores in plexiglass cylinders were dehydrated in an oven at $40^{\circ} \mathrm{C}$ until a constant weight, aiming to minimize possible interference by water films on the $\mathrm{X}$-rays attenuation, and then scanned at $120 \mathrm{kV}$ and $170 \mathrm{~mA}$ with an integration time of 3500 $\mathrm{mS}$, generating an $2 \mathrm{D}$ axial projection of $\mathrm{X}$-ray attenuation imagery, in microCT scan (EVS/GE MS8X-130), thirdgeneration preclinical, cone-beam, equipped with a tungsten X-ray tube. Excitation energy of $100 \mathrm{kV}$ and $130 \mathrm{~mA}$ was employed for all samples, in the Soil Image Laboratory at University of Guelph, Canada.

In order to obtain greater accuracy in the analysis and elimination of possible structural alterations generated during the sampling, a $0.033 \mathrm{~m}$ slice from the middle of the core was selected for scanning. As the X-ray source emits polychromatic X-rays (Clausnitzer; Hopmans, 2000), we employed prefiltering with a high-pass copper foil $(0.5 \mathrm{~mm})$ in order to reduce beam-hardening artifacts and to maximize the contrast between the different phases of the soil core (solid and air).

The 2D axial projections were acquired and reconstructed with $20 \mu \mathrm{m}$ spatial resolution (pixel size) and they were saved in 16-bit radiometric resolution. Then 3D subvolumes of interest were selected in the exact center of each original image and the reconstruction was done using a proprietary filtered back-projection software called "eXplore Reconstruction Utility" (GE Healthcare, 2006). The final isometric volume (666 voxel x 666 voxel x 550 slice) was reconstructed at $60 \mu \mathrm{m}$ voxel size, aiming to maximize both region of interest and spatial resolution, within a manageable $500 \mathrm{MB}$ file size (Figure 1).
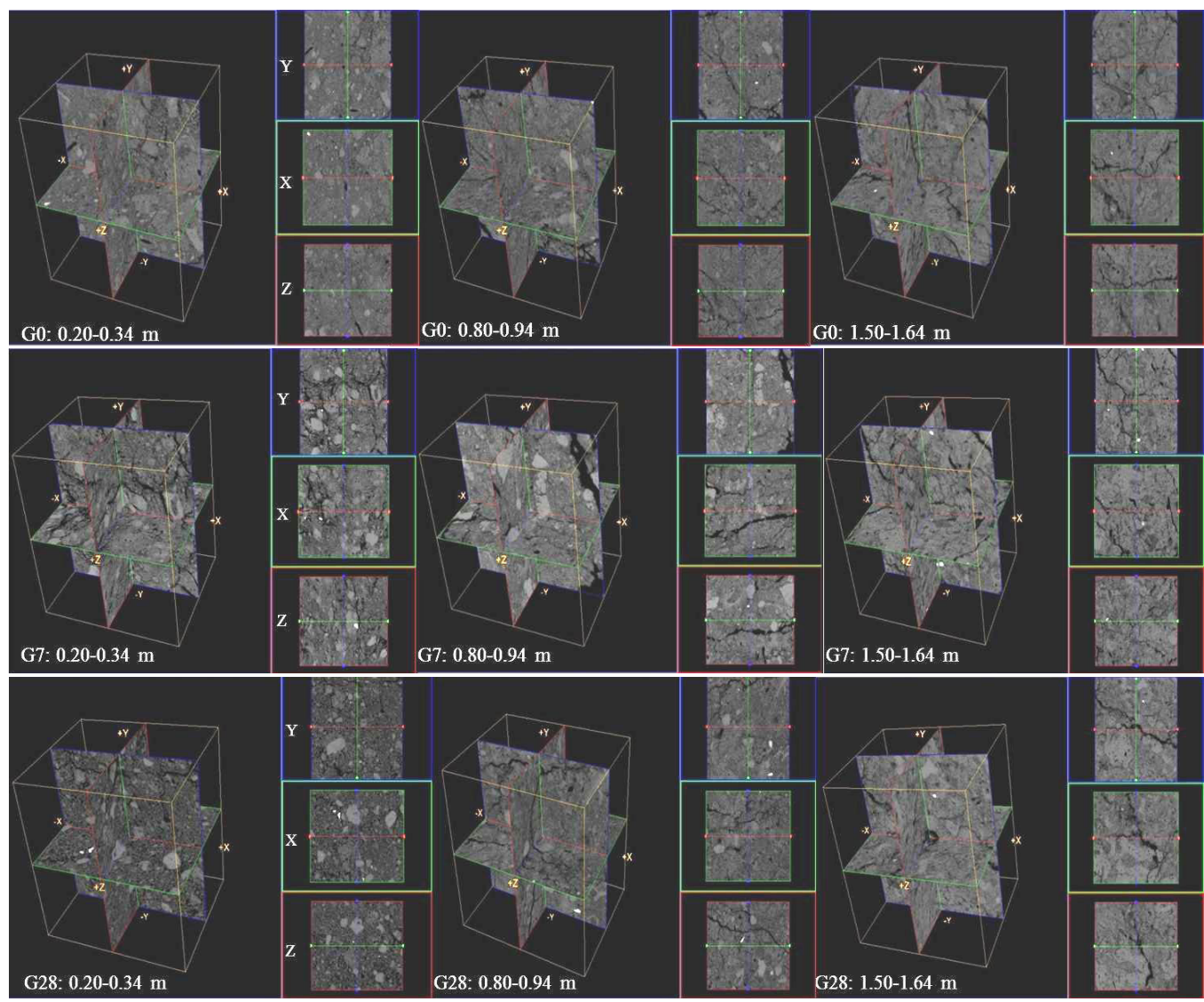

Figure 1 - Tomographic images of X-rays in soil samples $(3.5 \mathrm{~cm}$ thickness at the center of the sample) showing the typical microstructure of a Red Latosol under different treatments G0: absence gypsum, G7: $7 \mathrm{Mg} \mathrm{ha}^{-1}$ and G28: $28 \mathrm{Mg}$ $\mathrm{ha}^{-1}$ of additional gypsum applied on the soil surface in the plant row. The images on the right indicate the horizontal Y (blue), X (green) and vertical Z (red) orthogonal directions, and their combinations indicate the XY (top) horizontal planes, XZ (center) and the YZ (base) vertical planes. 
For the purpose of comparing the X-rays attenuation, in CT imagery, we used the values in Hounsfield scale (defined relative to air [-1000 HU] and water [0 HU]) and a calibration procedure through the use of two capillary tubes (one filled with water and the other with air inserted between the inner wall of the plexiglass tube and the sample at the time of scanning). Subsequently, the coefficients of water and air were calculated and a Gaussian smoothing filter (radius of 1 voxel) was used to reduce image noise and artifacts with the aid of MicroView (GE Healthcare, 2006) prior to subsequent analyses in NIH ImageJ (Rasband,2012).

\section{D image processing and analyzes}

The 3D image processing followed the protocol of the Soil Image Laboratory, University of Guelph, Canada. This is the first step in 3D image processing, which involves the conversion of each grayscale voxel value of the grayscale image (proportionally expressing the locations of the X-rays attenuation coefficients) into a binary image, distinguishing the void and non-void in the selected subvolume images.

The thresholding was done in NHI ImageJ (Rasband, 2012), by a method based on the work of Schlüter, Weller and Vogel (2010) employing both Laplacian edge detection and seeded-region-growing to assign the voxels associated with the zero-crossing, but first enforcing clamping of the gray-scale image (considering the histogram peak positions for air and solid), to minimize unnecessary edges.

With the public domain image analysis software $\mathrm{NIH}$ ImageJ, all analyzes were done in full 3D mode, which allowed differentiation of data categories according to the desired micro morphological size and shape classes.

To obtain the spatial data the "Semivariance 3D" plugin of the NIH ImageJ was used, with the X-rays attenuation value of the grayscale image. We obtained semivariances for the $3 \mathrm{D}$ image in grayscale, i.e., the orthogonal directions (X, Y, Z), where the semivariance is standardized [0-1]. The construction of the experimental semivariogram identified the spatial dependence amplitude of the variable under study and also defined the spatial variability structure (Goovaerts et al. 1999).

The "Analyze Particle" function of NHI ImageJ was used to calculate the pore dimensions (volume and area). This function detects and measures the objects in the binary image to obtain data relative to pores present in the image volume under study $(n=550)$. From this result the equivalent diameter to a sphere (3D images, spatial geometry simulation) and as the shape factor, the sphericity of the pore $(0=$ less rounded, angular, $1=$ more rounded and smooth) were calculated by equation 1 :

$$
\Psi=\pi^{1 / 3}(6 V)^{2 / 3} / A
$$

where: $\pi \approx 3.141592 \ldots 8, \mathrm{~V}=$ volume $\left(\mathrm{mm}^{3}\right)$ and $\mathrm{A}=$ area $\left(\mathrm{mm}^{2}\right)$.

\section{Statistical analyses}

Spatial analyses consisted of the construction of the experimental semivariogram from 3D images in grayscale.

The semivariance $\hat{y}$ is a function of the distance $h$ (Equation 2), which is estimated in a discrete set of lag distances expressed by a scatterplot that allows the variographic analysis of the spatial dependence amplitude of the variables studied (Faraco et al. 2008), in this case the $X$ and $Y$ orthogonal directions (horizontal direction) and $\mathrm{Z}$ (vertical direction), defining then the parameters required for the estimation of characteristics resulting from the spatial variability structure (Ávila, Mello; Silva, 2010). It is noteworthy that although we were working with 3 axis - directions $(\mathrm{X}, \mathrm{Y}, \mathrm{Z})$, the calculation of semivariance was given by $\mathrm{R}^{2}$, since we were working with the planes $\mathrm{X}, \mathrm{Y}$ and $\mathrm{Z}$. Thus, the standardized semivariograms were estimated by the classical method, through the estimator:

$$
\hat{y}(\mathrm{~h})=\frac{1}{2 \mathrm{~N}(\mathrm{~h})} \sum_{\mathrm{i}=1}^{\mathrm{N}(\mathrm{h})}\left[\mathrm{Z}\left(\mathrm{S}_{\mathrm{i}}\right)-\mathrm{Z}\left(\mathrm{S}_{\mathrm{i}}+\mathrm{h}\right)\right]^{2}
$$

in which: is the semivariance estimator, is the number of pairs of measured values, and, separated by a vector distance $h$, are realizations of the random variable (Journel, Huijbregts, 1978; Isaaks, Srivastava, 1989).

We then proceeded to estimate the experimental semivariance for each replication and using the average semivariance it was fitted to the exponential model (Equation 3), that presented the better fit of the data, and then the model parameters were determined: nugget effect $\left(\mathrm{C}_{0}\right)$, sill $\left(\mathrm{C}_{0}+\mathrm{C}_{1}\right)$ and theoretical and practical range (a), in $\mathrm{R}$ language ( $\mathrm{R}$ Development Core Team, 2012), more specifically with the 'geoR' package (Ribeiro Junior, Diggle, 2001), both having free access and in accordance with the GPL (General Public License):

$\hat{y}(h)=\left\{\begin{array}{cc}0 & ,|h|=0 \\ C_{0}+C_{1}\left[1-\exp \left(-\frac{|h|}{a}\right)\right], & |h| \neq 0\end{array}\right.$ 
Subsequently prediction intervals (PI) were constructed for the set of replications, in order to compare the spatial variability, as with the PI, so it can be stated that $95 \%$ of the samples were predicted.

The detectable pores were classified based on data mining by 'randomForest' package (Liaw; Weiner,2012), and other functions developed in $\mathrm{R}$ language ( $\mathrm{R}$ Development Core Team, 2012), where it was possible to generate various pore diameter classes and to detect the most contrasting ones. It generated 26 contrasting pore diameter classes distributed through a range of 0.2 to $1 \mathrm{~mm}$ in diameter, which corresponds to the limit between fine macropores and large mesopores (Bullock et al. 1985).

\section{RESULTS AND DISCUSSION}

The empirical semivariograms indicated secondorder stationarity for the variables evaluated, reflected by clear and well-defined sill (asymptote), which permitted identification of the spatial dependence range of the orthogonal directions (X, Y and $\mathrm{Z}$ ) of the 3D images in grayscale. Thus, the spatial variability structure was defined (Goovaerts et al. 1999), as well as the parameters necessary to estimate its characteristics (Figures 2-10).

This assessment was needed to verify the spatial dependence of the structural components (mineral portion and pore space) in each level combination (3 treatments $\mathrm{x} 3$ depths $\mathrm{x} 3$ directions) obtained through the axes(X, Y and $\mathrm{Z}$ ) of the $3 \mathrm{D}$ images. This allowed the identification of alterations promoted by the management system in question.

It was not possible to verify a distinct anisotropic structure only by visual observation of the semivariogram, thus by means of the prediction intervals (PI), the distinctions between events were revealed, where the 0.20-0.34 m, the G0 and the G7 showed the lowest range (a) (Figures 2 and 5), unlike G28 where a more pronounced narrowing occurred in the $0.80-0.94 \mathrm{~m}$ depth (Figure 9).

At the 1.50-1.64 m depth the treatments showed similarities, with greater PI and consequently higher sampling variability (Figures 4, 7 and 10). It should be emphasized that at this depth what prevails are the attributes inherent to the soil, arising from the frequency and organization of mineralogical components (Camargo et al. 2008).
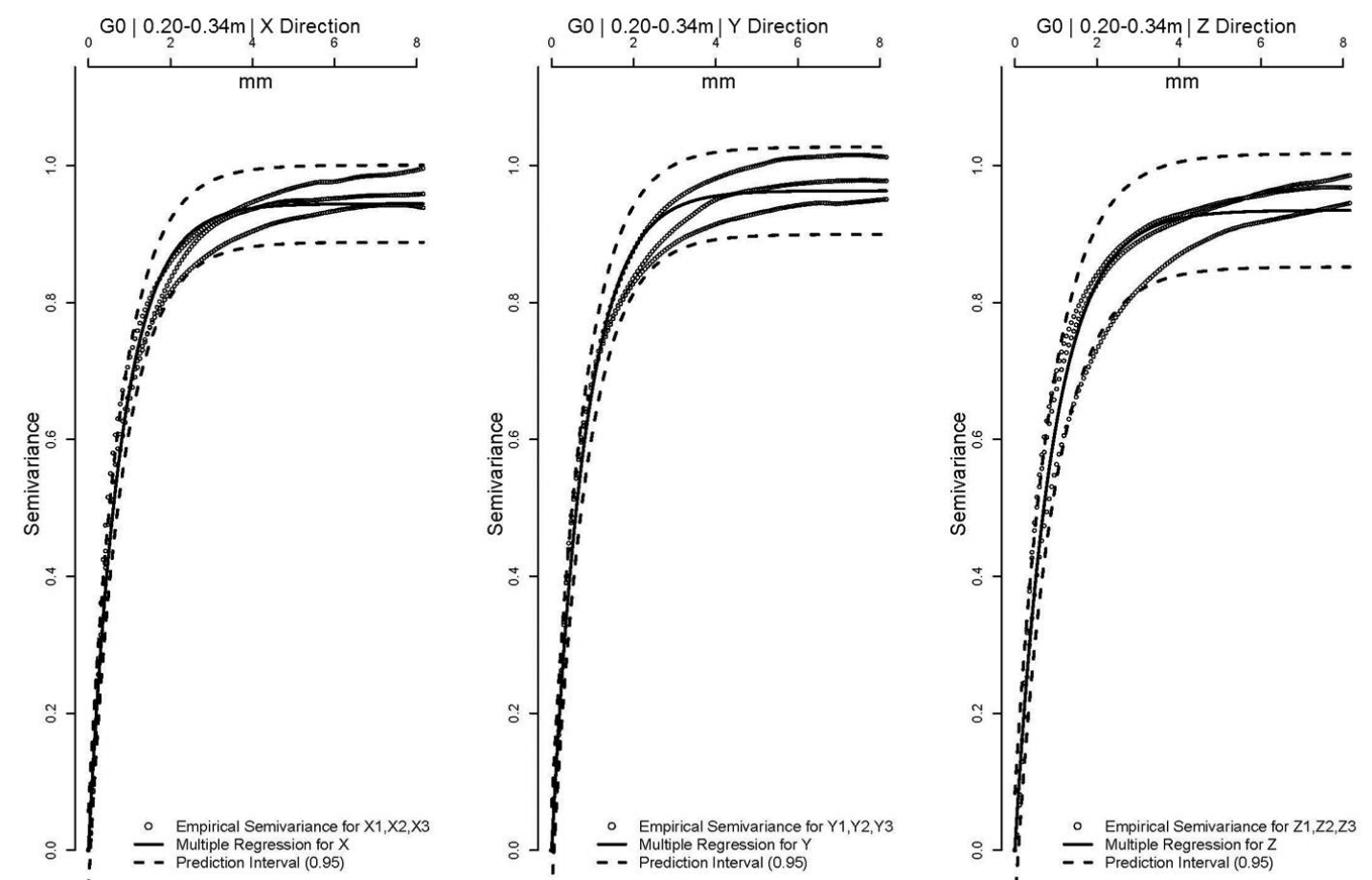

Figure 2 - Standard empirical semivariograms and theoretical exponential model fit to orthogonal directions $(\mathrm{X}, \mathrm{Y}, \mathrm{Z})$ at depths of 0.20-0.34 m, for G0 treatment (absence of additional gypsum). 

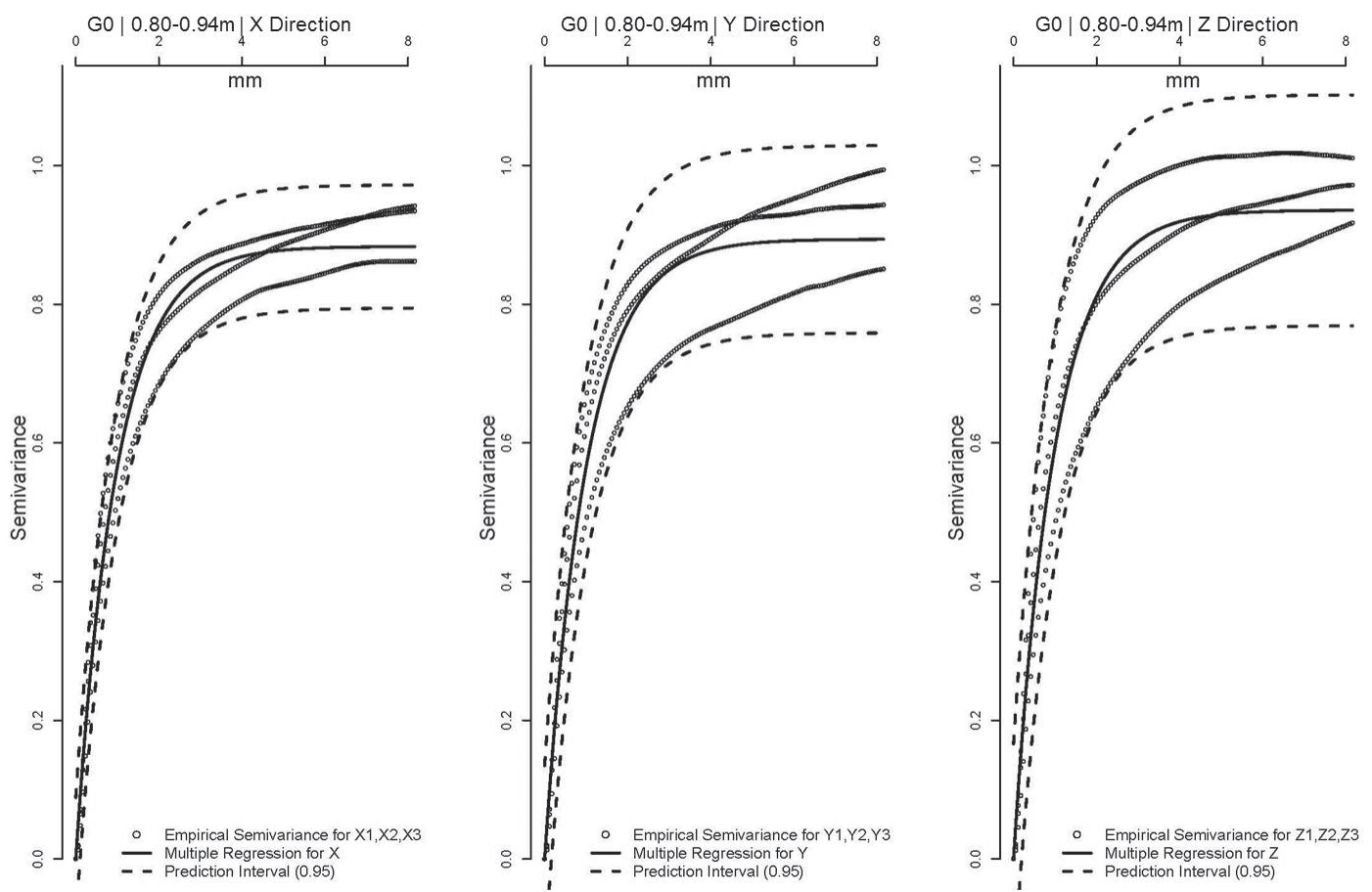

Figure 3 - Standard empirical semivariograms and theoretical exponential model fit to orthogonal directions $(\mathrm{X}, \mathrm{Y}, \mathrm{Z})$ at depths of 0.80-0.94 m, for G0 treatment (absence additional gypsum).
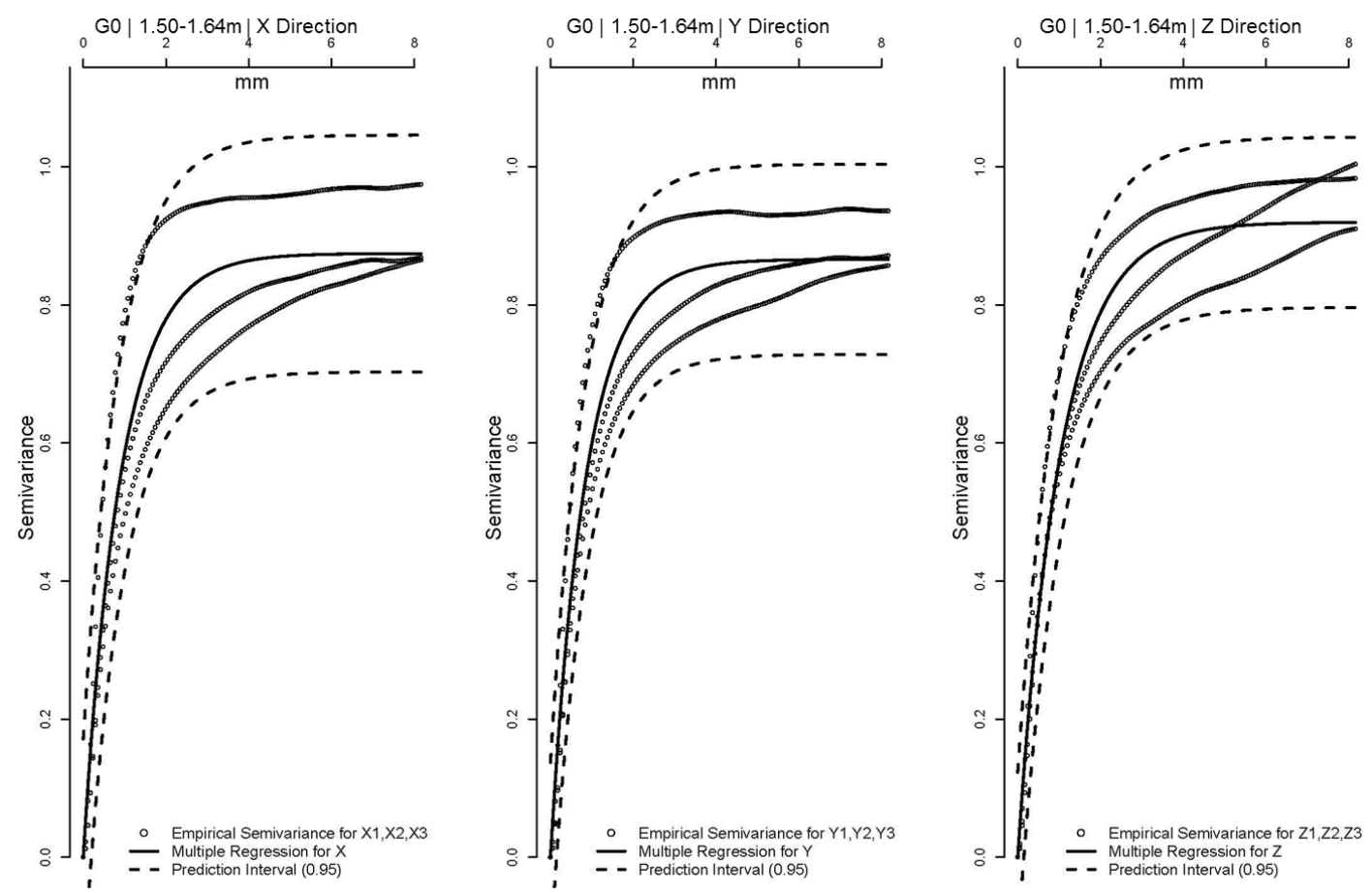

Figure 4 - Standard empirical semivariograms and theoretical exponential model fit to orthogonal directions (X, Y, Z) at depths of 1.50-1.64 m, for G0 treatment (absence additional gypsum). 

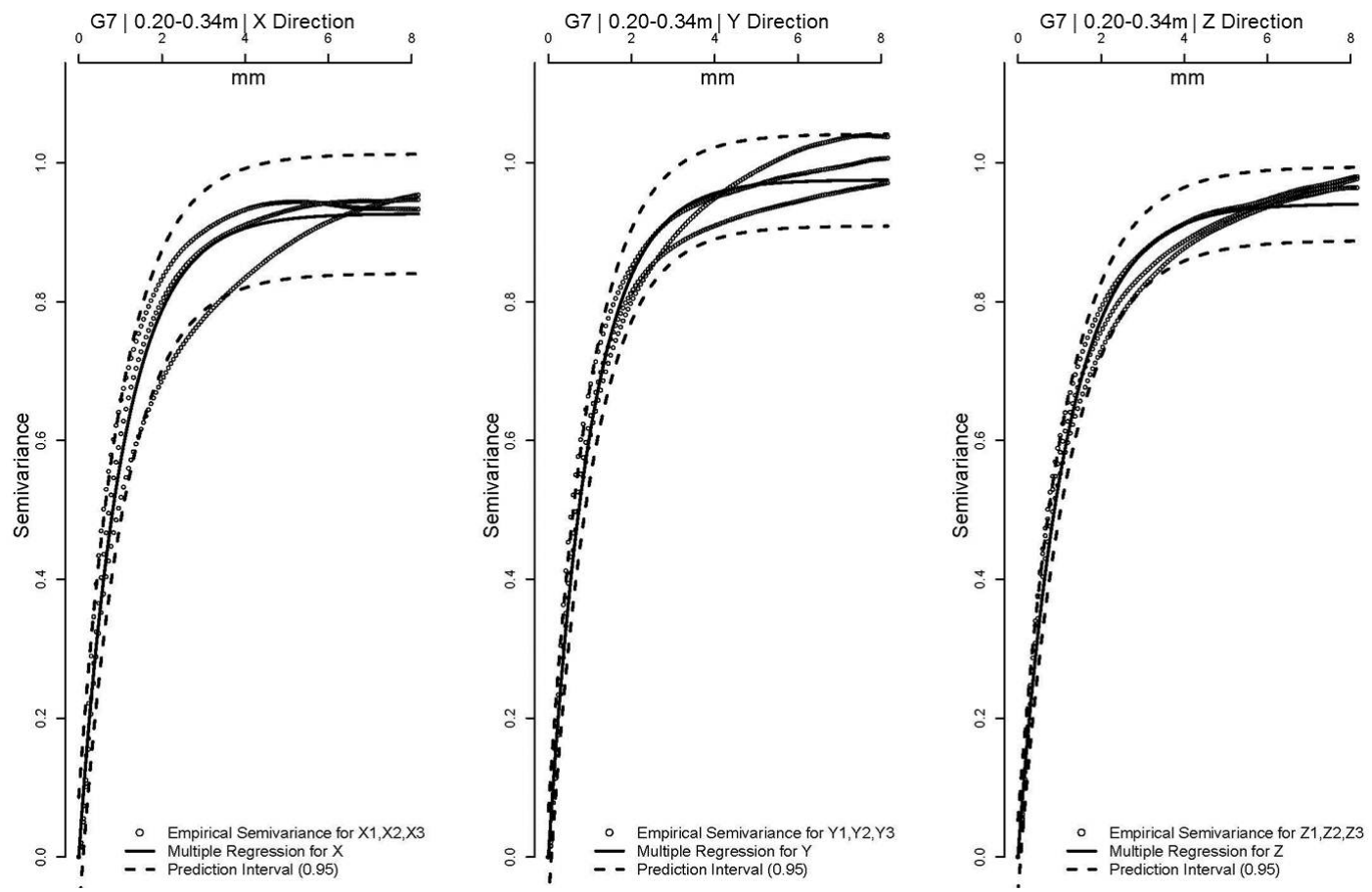

Figure 5 - Standardized empirical semivariograms and theoretical exponential model fit to orthogonal directions (X, Y, $\mathrm{Z}$ ) at depths of $0.20-0.34$, for $\mathrm{G} 7$ treatment ( $7 \mathrm{Mg} \mathrm{ha}^{-1}$ additional gypsum applied on the soil surface of the plant row).
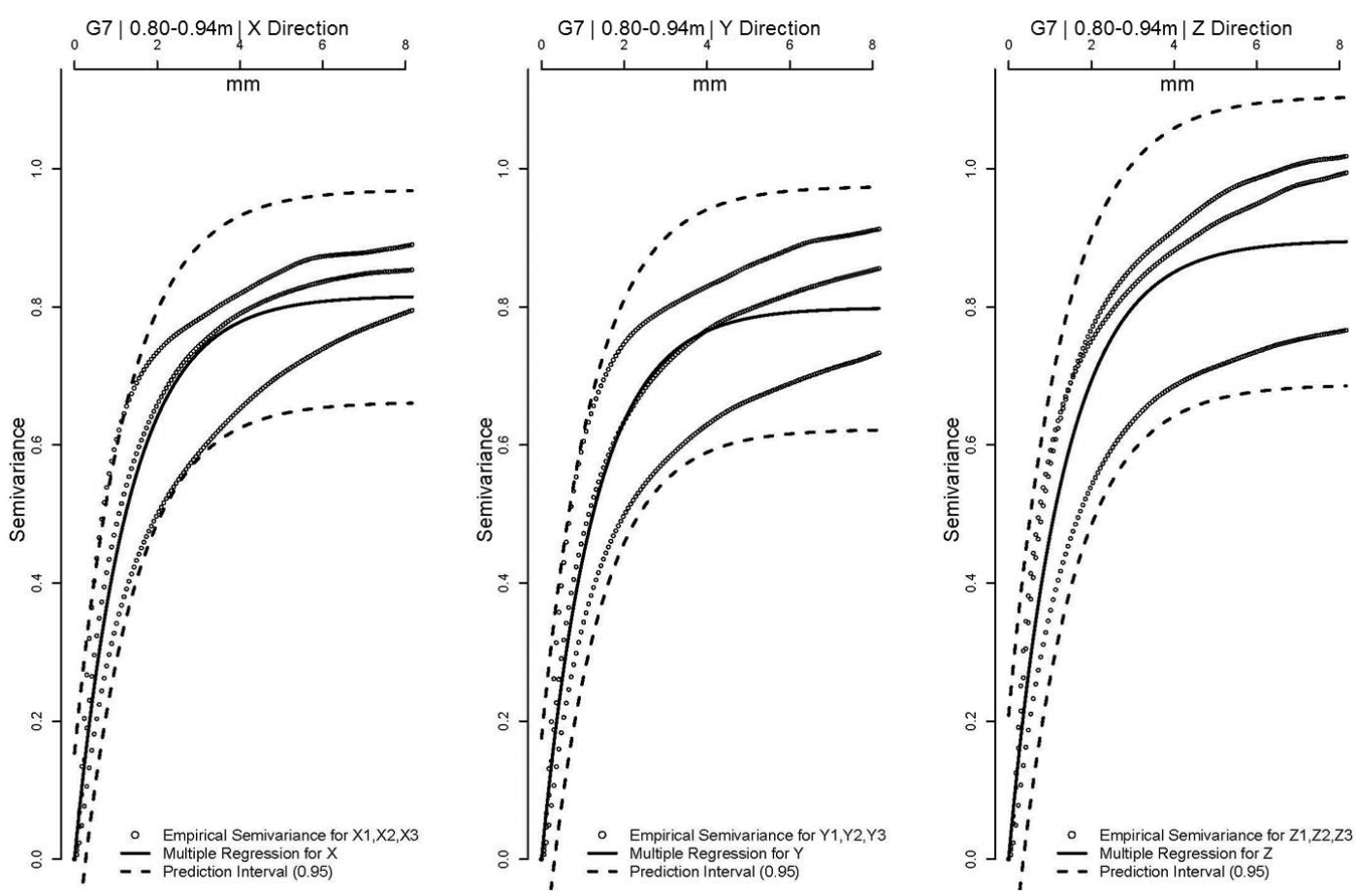

Figure 6 - Standardized empirical semivariograms and theoretical exponential model fit to orthogonal directions (X, Y, Z) at depths of $0.80-0.94 \mathrm{~m}$, for $\mathrm{G} 7$ treatment $\left(7 \mathrm{Mg} \mathrm{ha}^{-1}\right.$ additional gypsum applied on the soil surface of the plant row).

Ciênc. Agrotec., Lavras, v.38, n.5, p.445-460, set./out., 2014 

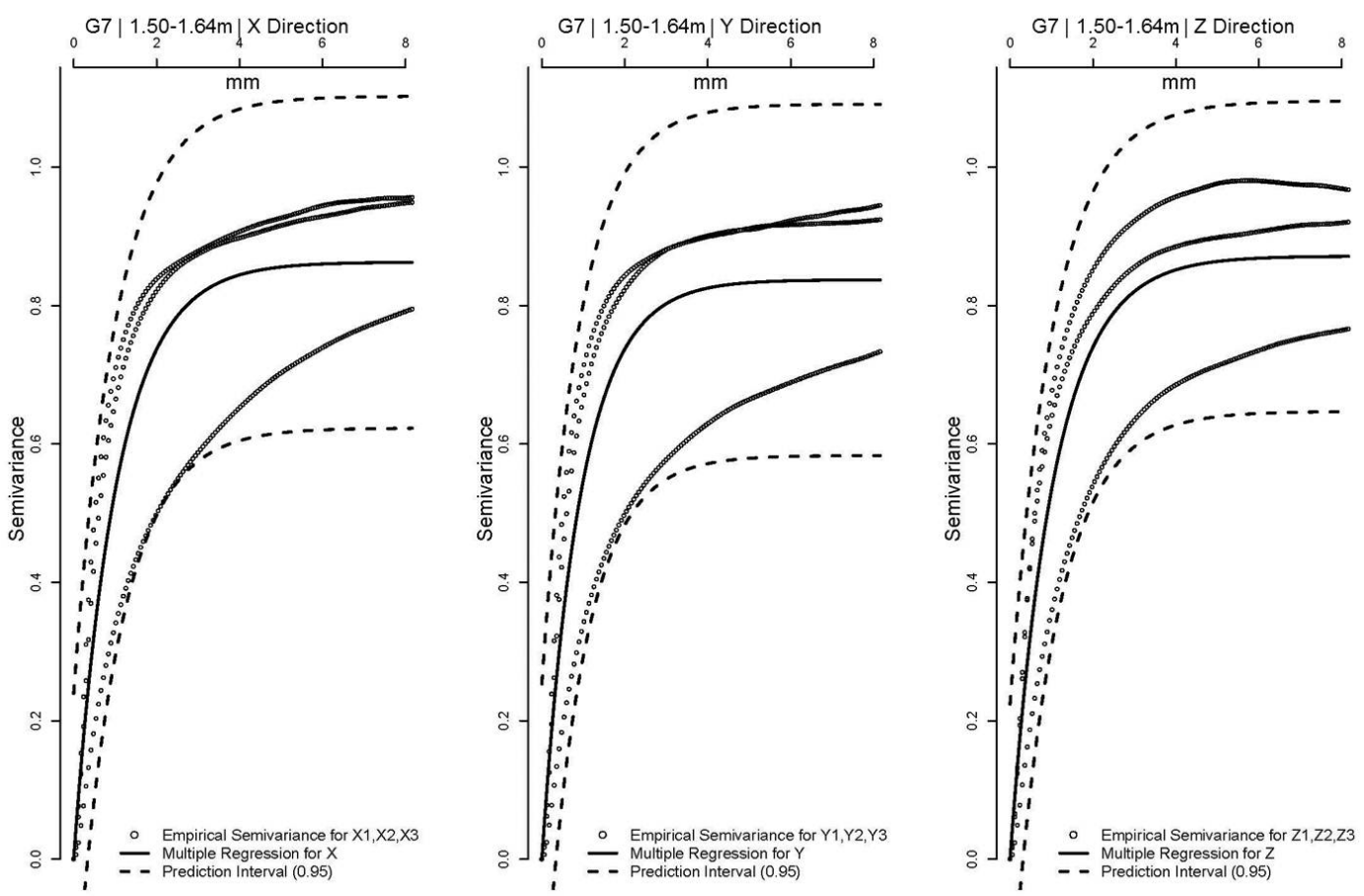

Figure 7 - Standardized empirical semivariograms and theoretical exponential model fit to orthogonal directions (X, Y, $\mathrm{Z}$ ) at depths of 1.50-1.64 m, for $\mathrm{G} 7$ treatment ( $7 \mathrm{Mg} \mathrm{ha}^{-1}$ added gypsum applied on the soil surface of the plant row).
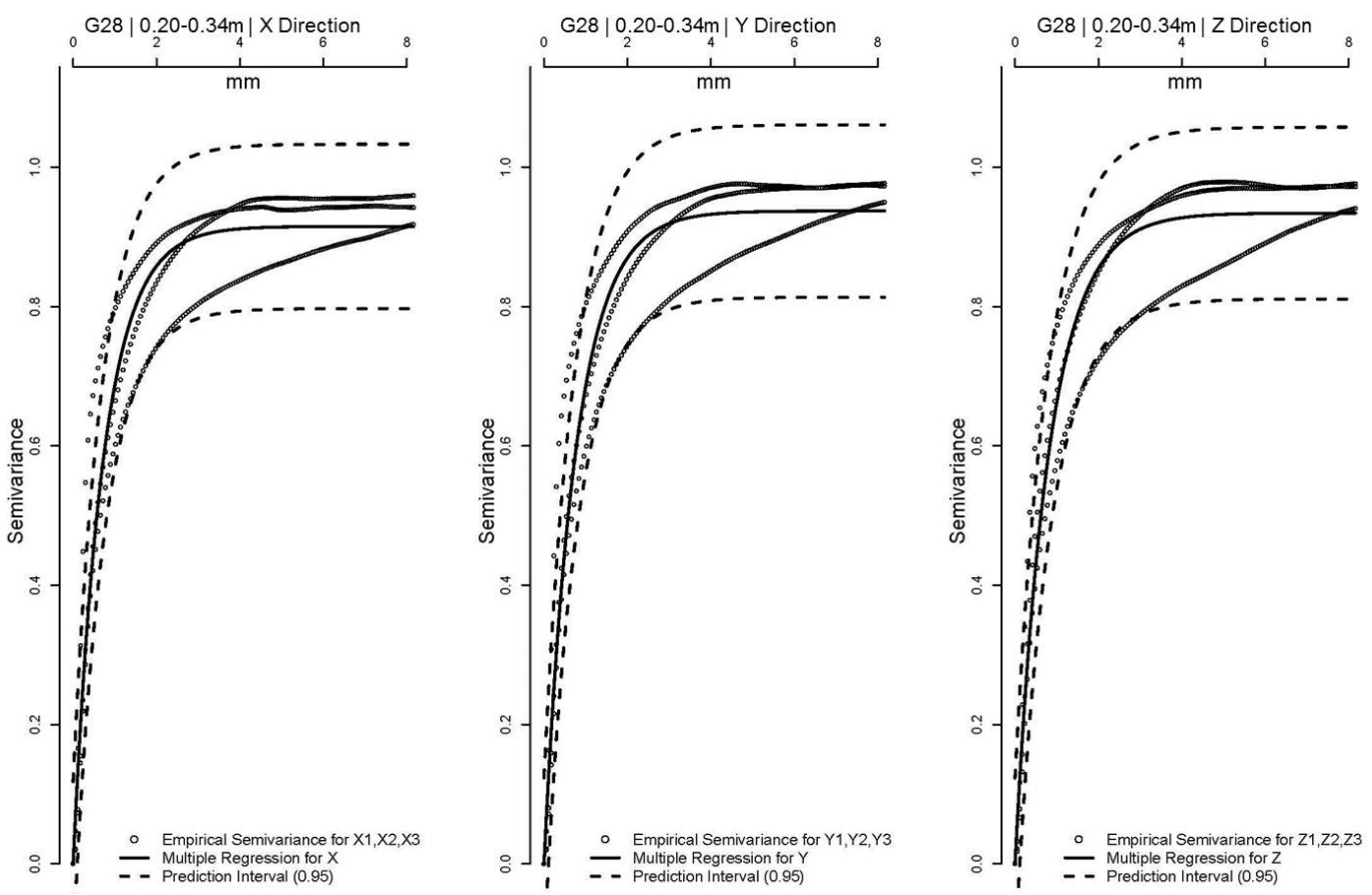

Figure 8 - Standardized empirical semivariograms and theoretical exponential model fit to orthogonal directions $(\mathrm{X}, \mathrm{Y}, \mathrm{Z})$ at depths of 0.20-0.34 m, for G28 treatment ( $28 \mathrm{Mg} \mathrm{ha}^{-1}$ additional gypsum applied on the soil surface of the plant row). 

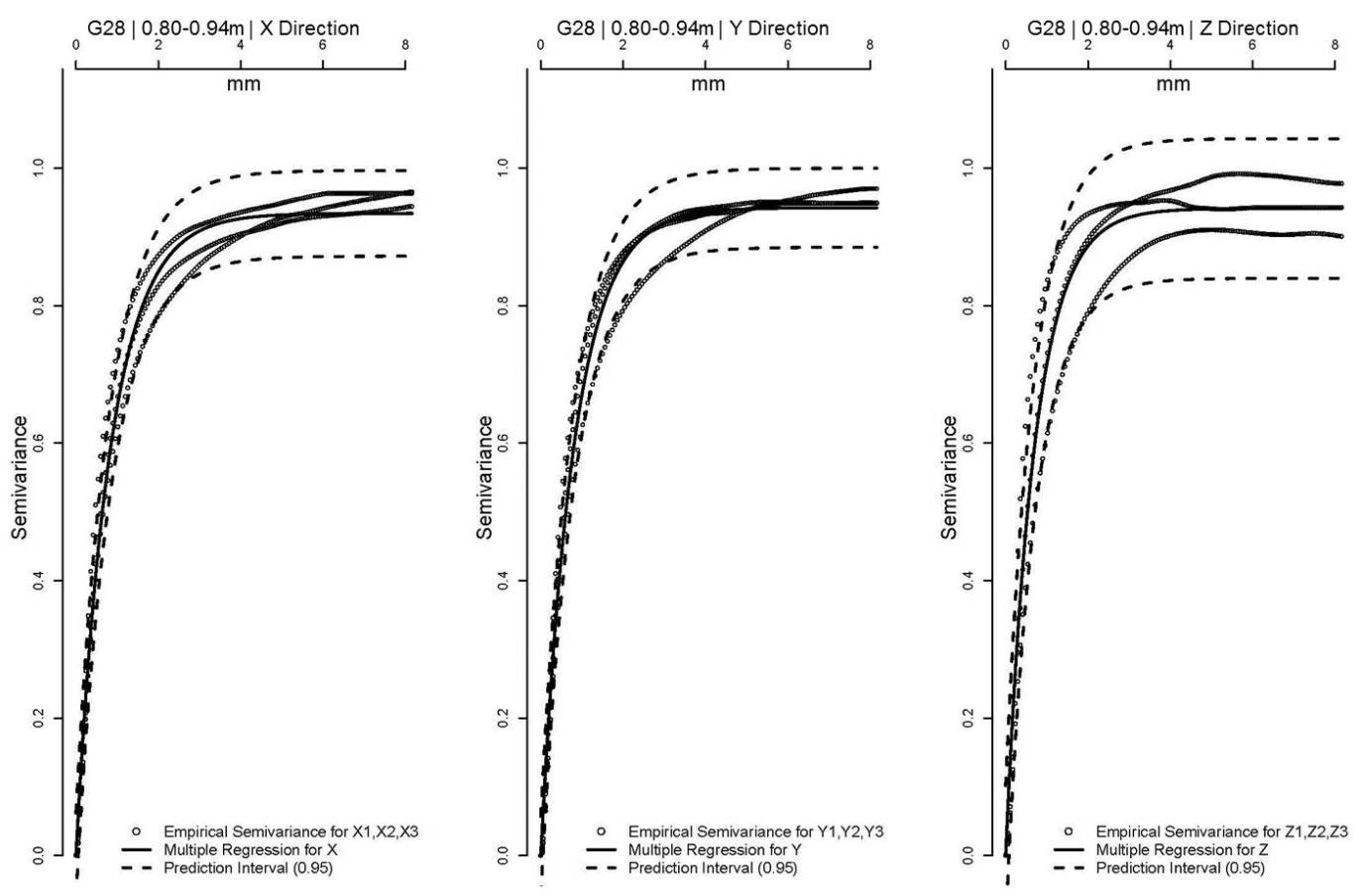

Figure 9 - Standardized empirical semivariograms and the oretical exponential model fit to orthogonal directions $(\mathrm{X}, \mathrm{Y}, \mathrm{Z})$ at depths of 0.80-0.94 m, for G28 treatment ( $28 \mathrm{Mg} \mathrm{ha}^{-1}$ additional gypsum applied on the soil surface of the plant row).
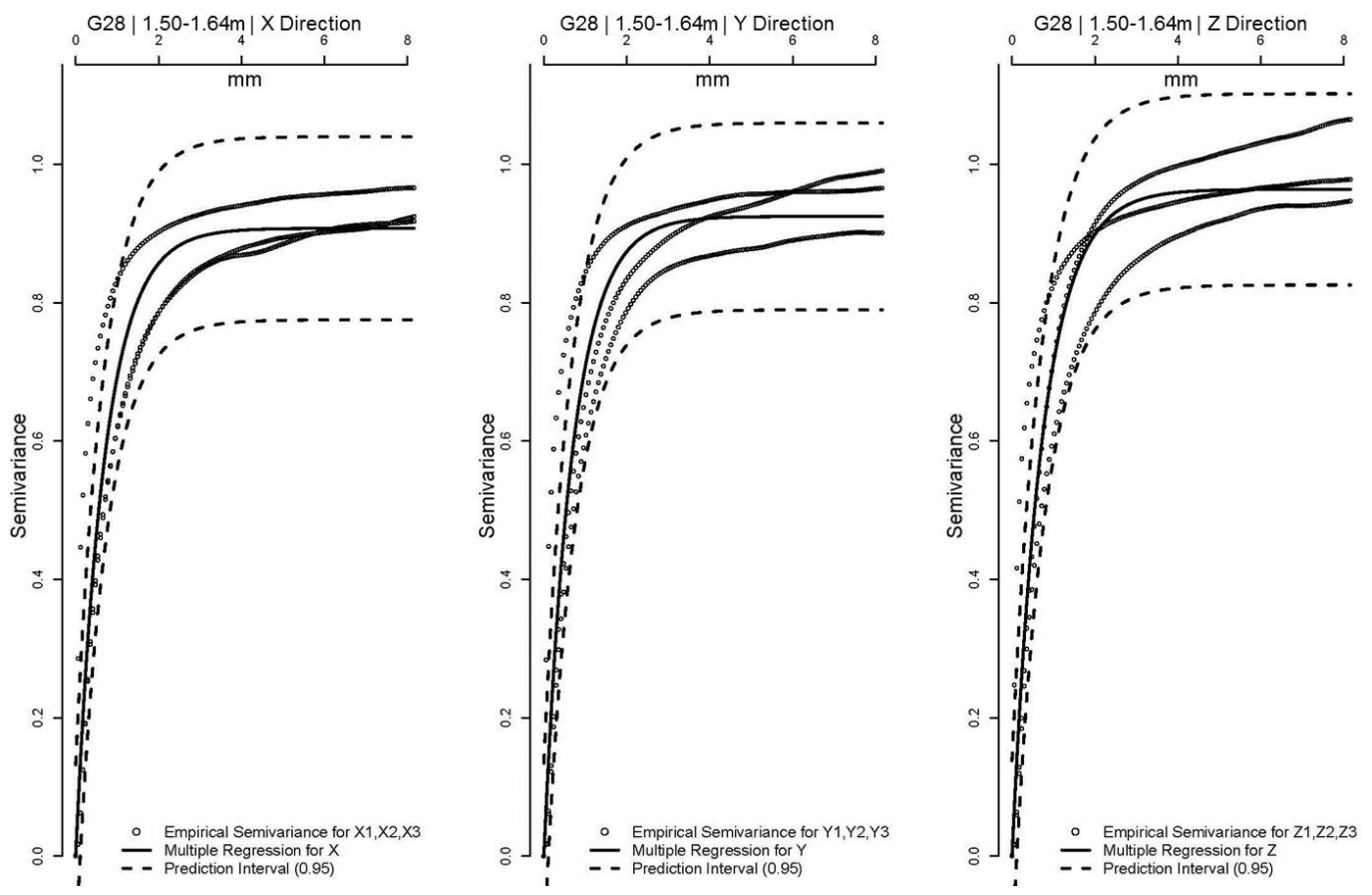

Figure 10 - Standardized empirical semivariograms and theoretical exponential model fit to orthogonal directions (X, $\mathrm{Y}, \mathrm{Z}$ ) at depths of 1.50-1.64 m, for G28 treatment (28 Mg ha-1 additional gypsum applied on the soil surface of the plant row).

Ciênc. Agrotec., Lavras, v.38, n.5, p.445-460, set./out., 2014 
The parameters of the fit variograms that best describe the soil structure spatial variability behavior are shown in table 3.

From the models obtained, the practical range (a) of the spatial dependence for the $\mathrm{X}, \mathrm{Y}$ and $\mathrm{Z}$ axes, the greater $(a)$ values were found in G7, at all depths, especially in the vertical direction (Z), followed by G0 and G28, respectively, at the $0.20-0.34$ and $1.50-1.64 \mathrm{~m}$ depth range and the horizontal directions ( $\mathrm{X}$ and $\mathrm{Y}$ ) at the 0.80-0.94 $\mathrm{m}$ depth range.
The $(a)$ indicates the magnitude of the spatial dependency, so that the higher range $(a)$ in $\mathrm{G} 7$ relative to the other treatments suggest the higher spatial continuity of the soil structure in the $\mathrm{X}, \mathrm{Y}$ and $\mathrm{Z}$ directions (Ávila, Mello; Silva,2010).

This facts probably due to amore homogeneous pore diameter distribution (Figure 11), with a possible decrease in macroporosity, which agrees with Schaffrath et al. (2008), that a possible pores homogenization may be related to a more uniform distribution of meso-aggregates

Table 3 - Parameters of the exponential model fit for the orthogonal directions (X, Y, Z) for the treatments, G0: absence of additional gypsum, G7: $7 \mathrm{Mg} \mathrm{ha}^{-1}$ and G28: $28 \mathrm{Mg} \mathrm{ha}^{-1}$ additional gypsum applied on the soil surface of the plant row.

\begin{tabular}{|c|c|c|c|c|c|}
\hline Treatments & Depth (m) & Orthogonal direction & $\left(\mathrm{C}_{0}+\mathrm{C}_{1}\right)$ & $a \mathrm{~T}(\mathrm{~mm})$ & $a \mathrm{P}(\mathrm{mm})$ \\
\hline G0 & $0.20-0.34$ & $\mathrm{X}$ & 0.9442 & 0.8067 & 2.4201 \\
\hline G0 & $0.20-0.34$ & $\mathrm{Y}$ & 0.9632 & 0.8268 & 2.4803 \\
\hline G0 & $0.20-0.34$ & $\mathrm{Z}$ & 0.9345 & 0.9212 & 2.7637 \\
\hline G0 & $0.80-0.94$ & $\mathrm{X}$ & 0.8832 & 0.9777 & 2.9332 \\
\hline G0 & $0.80-0.94$ & $\mathrm{Y}$ & 0.8938 & 0.9974 & 2.9921 \\
\hline G0 & $0.80-0.94$ & $\mathrm{Z}$ & 0.9356 & 0.9906 & 2.9718 \\
\hline G0 & $1.50-1.64$ & $\mathrm{X}$ & 0.8744 & 0.9013 & 2.7040 \\
\hline G0 & $1.50-1.64$ & $\mathrm{Y}$ & 0.8659 & 0,8485 & 2.5455 \\
\hline G0 & $1.50-1.64$ & $\mathrm{Z}$ & 0.9196 & 1.0255 & 3.0764 \\
\hline G7 & $0.20-0.34$ & $X$ & 0.9267 & 1.0543 & 3.1630 \\
\hline G7 & $0.20-0.34$ & $\mathrm{Y}$ & 0.9754 & 1.0198 & 3.0595 \\
\hline G7 & $0.20-0.34$ & $\mathrm{Z}$ & 0.9411 & 1.1560 & 3.4679 \\
\hline G7 & $0.80-0.94$ & $\mathrm{X}$ & 0.8159 & 1.3018 & 3.9054 \\
\hline G7 & $0.80-0.94$ & $\mathrm{Y}$ & 0.7987 & 1.2642 & 3.7927 \\
\hline G7 & $0.80-0.94$ & $\mathrm{Z}$ & 0.8964 & 1.3499 & 4.0497 \\
\hline G7 & $1.50-1.64$ & $\mathrm{X}$ & 0.8626 & 1.0394 & 3.1182 \\
\hline G7 & $1.50-1.64$ & $\mathrm{Y}$ & 0.8371 & 0.9412 & 2.8237 \\
\hline G7 & $1.50-1.64$ & $\mathrm{Z}$ & 0.8713 & 1.0571 & 3.1713 \\
\hline G28 & $0.20-0.34$ & $X$ & 0.9150 & 0.7202 & 2.1606 \\
\hline G28 & $0.20-0.34$ & $\mathrm{Y}$ & 0.9371 & 0.7589 & 2.2768 \\
\hline $\mathrm{G} 28$ & $0.20-0.34$ & $\mathrm{Z}$ & 0.9342 & 0.8111 & 2.4339 \\
\hline G28 & $0.80-0.94$ & $X$ & 0.9342 & 0.8340 & 2.5021 \\
\hline G28 & $0.80-0.94$ & $\mathrm{Y}$ & 0.9422 & 0.8031 & 2.4092 \\
\hline G28 & $0.80-0.94$ & $\mathrm{Z}$ & 0.9412 & 0.7005 & 2.1014 \\
\hline G28 & $1.50-1.64$ & $X$ & 0.9074 & 0.6939 & 2.0818 \\
\hline G28 & $1.50-1.64$ & $\mathrm{Y}$ & 0.9246 & 0.6897 & 2.0690 \\
\hline G28 & $1.50-1.64$ & Z & 0.9637 & 0.7412 & 2.2236 \\
\hline
\end{tabular}

$\mathrm{C}_{0}=$ Nugget effect was null; $\mathrm{C}_{0}+\mathrm{C}_{1}=$ still; $a \mathrm{~T}=$ range theoretical $(\mathrm{mm}) ; a \mathrm{P}=\operatorname{range}$ practical $(\mathrm{mm})$. 
(Costa Júnior et al. 2012), which was also observed by Silva et al. (2013) at a depth of $0.15 \mathrm{~m}$ in G7, working in the same area of this experimental research.

The formation and stability of macro- and microaggregates, which influence the distribution of space voids is strongly related primarily to the oxidic mineralogy and clay texture. This is similar to what occurs with Latosols of the chapadas of the Cerrado, due to electrostatic interactions between the oxides (mainly $\mathrm{Al}$ and $\mathrm{Fe}$ ), and external agents, such as those related to the adopted management system, since the biological agents have only a secondary importance (Costa Júnior et al. 2012; Vollant-Tuduri et al. 2005).

The spatial analysis performed, revealed that the effect of external agents, was identified, which is related to the gypsum amendment associated with other agricultural practices (Table 3 ).

In all experimental units ( 27 cases), the nugget effect was zero null (Table 3 ), due to the adequate spatial resolution $(60 \mu \mathrm{m})$ which generated a greater level of detail of the soil structure organization, i.e., within the limits of (a)and the still, most of the variability can be explained by the spatial component. The still had very similar values with a slight decrease in G7.

The highest IP, as well as the lowest $(a)$ values in the 0.20-0.34 m depth, occurred in the G28 (Figure 8 and Table 3 ) being explained by the presence of a greater volume of inter-aggregate pores, with diameters ranging from 0.3 to $0.6 \mathrm{~mm}$ (Figure 11).

The considerable occurrence of these pore diameters was most likely due to the combined effects of the management practices, primarily by the tillage occurred in preparing the plant row, that tends to homogenize the aggregates through the destruction of larger aggregates (Schaffrath et al. 2008; Cremon et al. 2009; Costa Júnior et al. 2012).
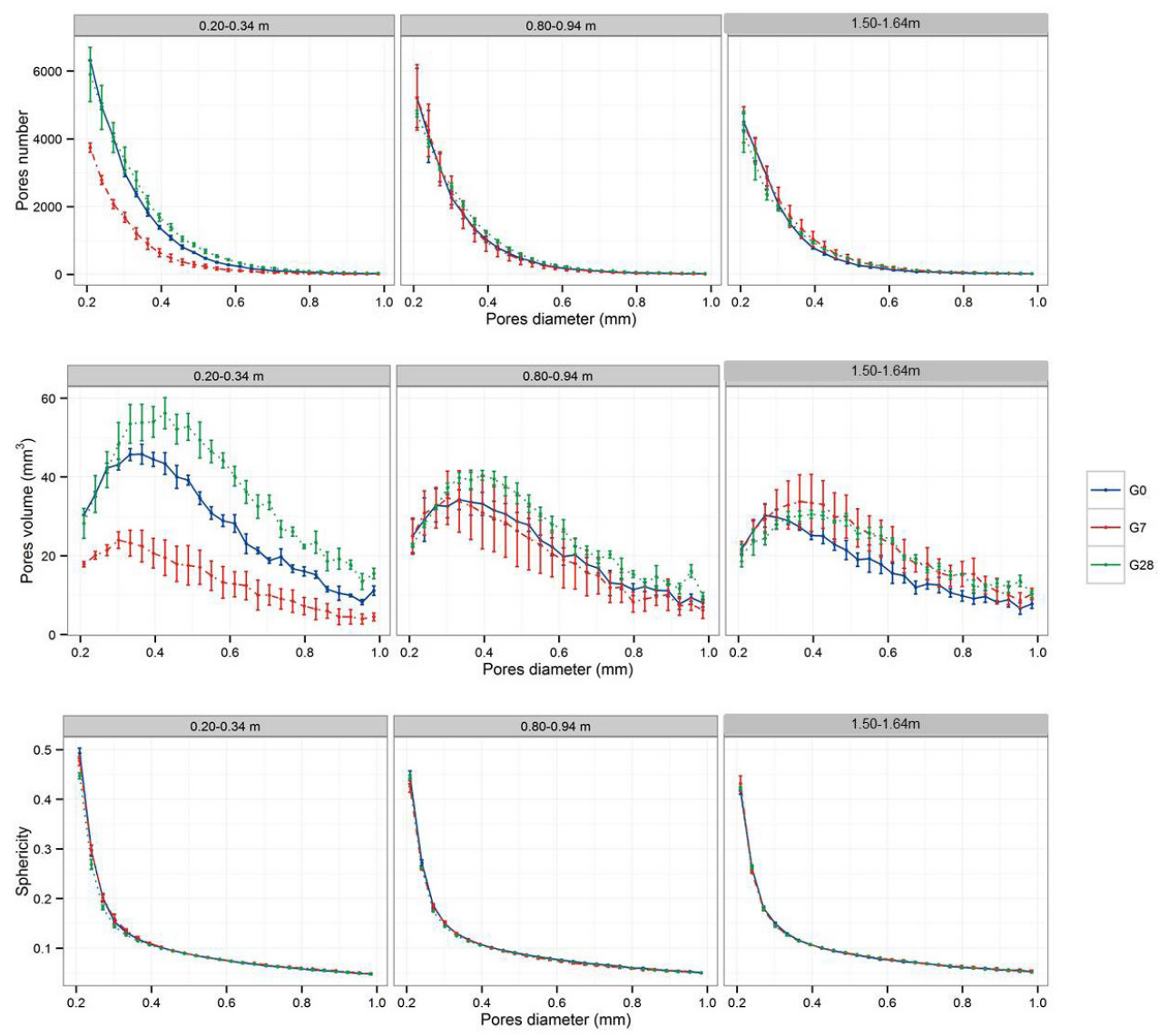

Figure 11 - Pore diameter distribution in number, volume and sphericity, respectively, of Red Latosol for the treatments G0: absence of additional gypsum, G7: $7 \mathrm{Mg} \mathrm{ha}^{-1}$ and G28: $28 \mathrm{Mg} \mathrm{ha}^{-1}$ of additional gypsum applied on the soil surface of the plant row. 
These new aggregates were formed possibly by the action of biological factors (Silva et al. 2013; Martin et al. 2012), via the constant supply of the organic material throughout the soil profile, by both the mowing of the interrow Brachiaria sp. and the renewal of the coffee roots, that increase the soil microorganism activity (mycorrhizal fungi, preferentially). This once associated acttore organize soil structure and diversify aggregates into different sizes (Costa Júnior et al. 2012, Martin et al. 2012; Cremon et al. 2009; Salton et al. 2008) which can promote the heterogeneity found in the pore diameter.

Accordingly, the soil management systems are considered a major source of spatial variability of soil physical properties (Schaffrathet al. 2008) and thus, exceptionally at the $0.20-0.34 \mathrm{~m}$ depth, the whole effect of the management practices for this system are being expressed by the pore diameter distribution.

The distinction between treatments was evident throughout the range generated especially in the classes of 0.3 to $0.6 \mathrm{~mm}$ in diameter with a greater number and volume of pores visible, i.e., they occupied a larger part of the soil matrix in the following order: G28 $>\mathrm{G} 0>\mathrm{G} 7$, especially at the $0.20-0.34 \mathrm{~m}$ depth.

The increase in the pore volume with a diameter less than $0.5 \mathrm{~mm}$ (Figure 11) especially at the 0.20-0.34 $\mathrm{m}$ depth, primarily for $\mathrm{G} 0$ and $\mathrm{G} 28$, may be related to the contribution of plant residue on the soil surface. That is associated to the development of specific mycorrhizal fungi, which favor the formation of a large number of smaller pores, originated from grouping of solid particles according to the growth of hyphae with a less diameter to than those of the pores, thus forming a network of these pore with fine roots of the plants, which favors the emergence of smaller aggregates (Martin et al. 2012).

On the other hand the amount of additional gypsum applied probably has secondary effects on the aggregate formation due to similarities in the pore distribution of G0 and $\mathrm{G} 28$ at the $0.20-0.34 \mathrm{~m}$ depth.

It is noteworthy that the gypsum is probably solubilized in a gradual manner, since besides being applied on the surface, it is covered with a thick layer of soil $(\approx 50$ $\mathrm{cm})$ together with an accumulation of biomass from the inter-row cut grass, and over time, accommodation of the particles occurs over it, thus creating a gypsum reservoir. Furthermore, as the region receives uneven rainfall distribution, a gradual release of the gypsum chemical components is favored (Serafim et al. 2011).

The adverse behavior of $\mathrm{G} 7$ in the same depth, regarding the number and volume of pores in the detectable diameter interval, deserves further studies.
It was found that in the $\mathrm{G} 7$, the exchangeable calcium $\left(\mathrm{Ca}^{2+}\right)$ is the predominant ionic species in the soil solution, with values of 1.6 and $13 \mathrm{mmol}_{\mathrm{c}} \mathrm{dm}^{-3}$ in G0 and G7, respectively, at $0.15-0.25 \mathrm{~m}$ depth after 16 months of crop implantation. After 2.5 years was 27 and50 mmol $\mathrm{dm}^{-3}$ in G0 and G7, respectively, and in G28 was $48 \mathrm{mmol}_{\mathrm{c}}^{\mathrm{c}}$ $\mathrm{dm}^{-3}$ (Silva et al. 2013; Ramos et al. 2013).

In $\mathrm{G} 7$ quantities are insufficient to act as an aggregate dispersing agent (Spera et al. 2008; Cremon et al. 2009). Even it is important to point out that the highest spatial continuity of pores found in the range evaluated could be positive if there was a proportional increase in the smaller pores number responsible for the higher retention of available water to plants.

The por spatial distribution of greater diameter throughout the soil profile influences the equilibrium of soil physical-hydric processes. The knowledge of pores spatial geometry which controls the increment in number and area of pores, as well as their tortuosity, contributes to the understanding of the alterations that may occur in the soil processes dynamics, influenced by agricultural practices (Luo; Lin; Li, 2010).

With respect to the sphericity that indicates the surface roughness of the pores $(0=$ roughness, $1=$ rounded), it increased with decreasing pore diameter, as observed by Tippkötter et al. (2009) (Figure 11). Sphericity was similar throughout the soil profile, which is attributed to the micro-granular type structure favored mainly by the high gibbsite content (Table 1) that acts in the formation of the very small micro-aggregates and more rounded micropeds (Vidal-Torrado et al. 1999; Ferreira, Fernandes; Curi 1999).

The sphericity of the pores was remarkable at the $0.20-0.34 \mathrm{~m}$ depth and this fact may be related to both the oxidic-gibbsitic mineralogy and the effects of soil tillage in the plant row, which tends to form smaller and more rounded aggregates, via the breakdown of the larger ones, as macro-morphologically observed by Cremon et al. (2009).

\section{CONCLUSIONS}

A greater spatial continuity of pores was detected in G7 at the depths evaluated.

A highly homogeneous distribution of the visible pores volume in each class occurred in G7 especially at $0.20-0.34 \mathrm{~m}$ depth.

The largest pore number and volume were detected in G28 in the $0.20-0.34 \mathrm{~m}$ depth, as well as the greatest spatial variability of soil structure, promoted by the effect of combined practices of the management system. 
Based on geostatistical analyses, it can be inferred that the adoption of the management system under study promoted changes in the pore network in all directions (X, $\mathrm{Y}$ and $\mathrm{Z}$ ), but with better pores continuity in the vertical direction $(Z)$.

\section{ACKNOWLEDGMENTS}

To FAPEMIG for research funding; to Consórcio Embrapa Café for the vehicle loan; $\mathrm{CNPq}$ for granting the scholarship; UFLA for the institutional support; to Empresa AP for technical and logistical support. To the DCS-UFLA D.Sc. student Teotônio Soares for the R language support.

\section{REFERENCES}

ÁVILA, L. F.; MELLO, C.R.; SILVA, A. M.

Continuidade e distribuição espacial da umidade do solo em bacia hidrográfica da Serra da Mantiqueira. Revista Brasileira de Engenharia Agrícola e Ambiental. 14(12):1257-1266, 2010.

BORGES, J. A. R.; PIRES, L. F. Representative elementary area (REA) in soil bulk density measurements through gamma ray computed tomography. Soil and Tillage Research. 123(1):43-49, 2012 .

BULLOCK, P. et al. Handbook for Soil Thin Section Description. Waine Research Publications, England, 1985.152p.

CARDUCCI, C. E. et al. Bimodal pore distribution on soils under conservationist management system for coffee crop. Engenharia Agrícola. 33(2):291-302, 2013.

CAMARGO, L. A. et al. Variabilidade espacial de atributos mineralógicos de um Latossolo sob diferentes formas do relevo. I - mineralogia da fração argila.

Revista Brasileira de Ciência do Solo. 32(6):22692277, 2008.

CLAUSNITZER, V.; HOPMANS, J. W. Pore-scale measurements of solute breakthrough using microfocus X-ray computed tomography. Water Resources Research. 36(8):2067-2079, 2000.

COOPER, M.; VIDAL-TORRADO, P. Caracterização morfológica, micromorfológica e físico-hídrica de solos com horizonte B nítico. Revista Brasileira de Ciência do Solo. 29(4):581-595, 2005.

COSTA JUNIOR, C. et al. Carbono em agregados do solo sob vegetação nativa, pastagem e sistemas agrícolas no Bioma Cerrado. Revista Brasileira de Ciência do Solo. 36(4):1311-1321, 2012.

CREMON, C. et al. Análise micromorfométrica de agregados de um Latossolo Vermelho Distroférrico em diferentes sistemas de manejo. Acta Scientiarum Agronomy. 31(1):139-146, 2009.

EMPRESA BRASILEIRA DE PESQUISA AGROPECUÁRIA. Centro Nacional de Pesquisa de Solos. Manual de métodos de análise de solo. 2. ed. revista. Rio de Janeiro, 2011. 225p.

Centro Nacional

de Pesquisa de Solos. Sistema brasileiro de

classificação de solos. 3. ed. Rio de Janeiro, 2013. $353 \mathrm{p}$.

FARACO, M. A. et al. Seleção de modelos de variabilidade espacial para elaboração de mapas temáticos de atributos físicos do solo e produtividade da soja. Revista Brasileira de Ciência do Solo. 32(2):463476, 2008.

FERREIRA, M. M.; FERNADES, B.; CURI, N. Mineralogia da fração argila e estrutura de Latossolos da região sudeste do Brasil. Revista Brasileira de Ciência do Solo. 23(1):507-514, 1999.

GE HEALTHCARE (2006). Microview Analysis 2.2. Technical Publication. Direction 2407688. Revision 1. [Online]. Available in : $<$ http://www.oucom.ohiou.edu/ ou-microct $>2011$.

GOOVAERTS, P. Geostatistics in soil science: stateof-the-art and perspectives. Geoderma. 89(1-2):1-45, 1999.

ISAAKS E. H.; SRIVASTAVA, R. M. An introduction to applied geostatistics. (Oxford University Press: New York).1989. 561p.

JOURNEL, A.; HUIJBREGTS, C.J. Mining geoestatistics. San Diego: Academic, 1978. 600p. 
LIAW, A.; WIENER, M. Package 'randomForest':

Breiman and Cutler's random forests for classification and regression. Version 4.6-7. Available in: $<$ http://stat-www.berkeley.edu/users/breiman/ RandomForests $>2012$.

LUO, L.; LIN, H.; LI, S. Quantification of 3-D soil macropore networks in different soil types and land uses using computed tomography. Journal of Hydrology. 393(1-2):53-64, 2010.

MARTIN, S.L. et al. The effects of simultaneous root colonisation by three Glomus species on soil pore characteristics. Soil Biology and Biochemistry. 49(6):167-173, 2012.

MENEGASSE, L.N.; GONÇALVES, J.M.; FANTINEL, L.M. Disponibilidades hídricas na Província Cárstica de Arcos- Pains-Doresópolis, Alto São Francisco, Minas Gerais, Brasil. Revista Águas Subterrâneas. 16(1):119, 2002.

MUNKHOLM, L. J.; HECK, R.J.; DEEN, B. Soil pore characteristics assessed from X-ray micro-CT derived images and correlations to soil friability.

Geoderma.181-182(1):22-29, 2012.

OLIVEIRA, G. C. et al. Caracterização química e físico-hídrica de um Latossolo Vermelho após vinte anos de Manejo e cultivo do solo. Revista Brasileira de Ciência do Solo. 28(2):327-336, 2004.

RAIJ, B.V. Gesso na agricultura. Campinas: Instituto Agronômico, 2008. 233p.

RAMOS, B. Z. et al. Doses de gesso em cafeeiro: influência nos teores de cálcio, magnésio, potássio e pH na solução de um Latossolo Vermelho distrófico. Revista Brasileira de Ciência do Solo. 37(4):1018-1026, 2013.

\section{RASBAND, W. ImageJ: Image processing and} analysis in Java (Online) (1992- 2012). Available at Research Services Branch, National Institute of Health. Bethesda, MD, USA. Available in: $<$ http://rsb.info.nih. gov/ij/index.html $>2012$.

R DEVELOPMENT CORE TEAM. R: a language and environment for statistical computing. Vienna: $\mathrm{R}$ Foundation for Statistical Computing, 2012. Available in: $<$ http://www.R-project.org $>2012$.
RESENDE, M.; BAHIA FILHO, A. F. C.; BRAGA, J. M. Mineralogia da argila de Latossolos estimada por alocação a partir do teor total de óxidos do ataque sulfúrico. Revista Brasileira de Ciência do Solo. 11(1):17-23,1987.

RIBEIRO JUNIOR P. J.; DIGGLE, P. J. geoR: a package for geoestatistical analysis. R-News.1(2):15-18, 2001.

SALTON, J. C. et al. Agregação e estabilidade de agregados do solo em sistemas agropecuários em mato grosso do sul. Revista Brasileira de Ciência do Solo. 32(1):11-21, 2008.

SANTOS, R. D. et al. Manual de descrição e coleta de solo no campo. ed. 6. Sociedade Brasileira de Ciência do Solo, Viçosa, MG, 2013.100p.

SCHAFFRATH, V. R. et al. Variabilidade e correlação espacial de propriedades físicas de solo sob plantio direto e preparo convencional. Revista Brasileira de Ciência do Solo. 32(4):1369-1377, 2008.

SCHLÜTER, S.; WELLER, U.; VOGEL, H. J. Segmentation of X-ray microtomography images of soil using gradient masks. Computer Geoscience. 36(10):1246-1251, 2010.

SERAFIM, M. E. et al. Sistema conservacionista e de manejo intensivo do solo no cultivo de cafeeiros na região do Alto São Francisco, MG: um estudo de caso. Bioscience Journal. 27(6):964-977, 2011.

SEVERIANO, E. C. et al. Preconsolidation pressure, soil water retention characteristics, and texture of Latosols in the Brazilian Cerrado. Soil Research. 51(3):193-202, 2013.

SILVA, A. E. et al. Doses crescentes de gesso agrícola, estabilidade de agregados e carbono orgânico em Latossolo do Cerrado sob cafeicultura. Revista Ciências Agrarias. 56(1):25-32, 2013.

SPERA, S. T. et al. Dispersão de argila em micro agregados de solo incubado com calcário. Revista Brasileira de Ciência do Solo. 32(n.spe):2613-2620, 2008. 
TICIANEL, T. Sistema Mafes (Penta). Empresa Mafes. Available in: < http://www.lpv.esalq.usp.br/lpv584/ SISTEMA_MAFES\%20por\%20Tulio\%20Ticianel.pdf> 2013.

TIPPKÖTTER, R. et al. Detection of soil water in macropores of undisturbed soil using microfocus X-ray tube computerized tomography $(\mu \mathrm{CT})$. Soil and Tillage Research. 105(1):12-20, 2009.
VIDAL-TORRADO, P. et al. Pedogênese em uma seqüência Latossolo podzólico na borda de um platô na depressão periférica paulista. Revista Brasileira de Ciência do Solo. 23(4):909-921, 1999.

VOLLANT-TUDURI, N. et al. Mass proportion of microaggregates and bulk density in a Brazilian clayey Oxisol. Soil Science Society of America Journal. 69(5):1559-1564, 2005. 